\title{
Genomic Epidemiology of Congestive Heart Disease, Pharmacogenomics and the Relevant Health Education Implications in the Age of Genomic Medicine
}

\author{
E. William Ebomoyi ${ }^{*}$ \\ ${ }^{1}$ Department of Health Studies, College of Health Sciences, Chicago State University, \\ Chicago, Illinois 60628-1598, United States of America.
}

Review Article

Received $23^{\text {rd }}$ July 2011

Accepted 26 ${ }^{\text {th }}$ July 2011

Online Ready $31^{\text {st }}$ July 2011

\section{ABSTRACT}

This project investigated genomic epidemiology of congestive heart disease, the clinical and non-invasive techniques for diagnosis and the modifiable and non-modifiable risk factors associated with the disease were explored. Trends in the morbidity and mortality of CHD revealed an increase in the disease frequency with minor drop in its' trajectory into the twenty-first century. While the modifiable risk factors were discussed with suitable interventions, the non-modifiable risk factors demand prompt medical diagnosis and treatment if any. The genes incriminated were listed. The relevance of pharmacogenomics cannot be overstated in the age of genomic medical science. But by far most important is the consumption of food items rich in phyto-nutrients to maximize public health and minimize the impact of dangerous lipids in our diet.

Keywords: Genomic epidemiology; public health genomics; modifiable and non-modifiable risk factors; congestive heart disease; invasive and non-invasive interventions; pharmaco-genomics; phyto-nutrients; 


\section{INTRODUCTION}

Mausner and Bahn (1987) defined epidemiology as "the scientific study of the determinants and distribution of diseases and injuries in human population." In the same vein, genetic epidemiology has been conceptualized as the science which focuses on assessing the etiology, distribution and control of disease in groups of people with intra-familial linkage with inherited causes of disease in population. Khoury Muin and Associates (1993) further explained genetic epidemiology as "the study of the role of genetic factors and the interaction with environmental factors in the occurrence of diseases in populations." In the age of genomic science, genomics implies the interaction of genes with other genes and the environment. Genome-based innovative technologies have revolutionized scientific knowledge about the incipient onset of congestive heart disease. This abnormality occurs when the heart is unable to pump blood efficiently and does not deliver sufficient oxygen to various parts of the body. There are many underlying causes of disease which lead to congestive heart failure. Among them are undiagnosed, untreated and inefficiently managed high blood pressure and other diseases of the heart and kidney.

From clinical epidemiologic studies, congestive heart disease is a condition which reflects impairment of the pumping function of the left ventricle of the heart. Consequently blood flow from the left ventricle into the aorta and to the peripheral arterial circulation is reduced. Also failure to eject blood from the left ventricle culminates in increased back-pressure to complete the signs and symptoms of the disease.

\section{CLINICAL DIAGNOSIS}

Frequently reported symptoms of congestive heart failure (CHF) include shortness of breath, easily getting fatigue, waking up at night with impaired breathing, swollen feet and ankle and unexplained weight gain due to fluid overload and loss of appetite. In many males there is the incipient onset of absolute impotence and routine sluggishness and lethargy. An interdisciplinary team of physicians are able to clinically diagnose congestive heart failure by having their patients undergo many non-invasive tests. Patients undergo chest-X-ray, electrocardiogram (ECG), blood test for cardiac enzymes analysis, echocardiogram and cardiac catherization. While chest X-Ray is used to evaluate the heart size and pulmonary congestion, ECG is employed to confirm any cardiac changes, heart enlargement and cardiac enzymes are assessed to clarify if the patient's cardiac muscles were damaged as infant or as young adult and if the age of the patient has potentiated weakened cardiac muscles. Echocardiography measures cardiac output and venous engorgement in both pulmonary and systemic circulation. In many patients over the age of 60 , the magnetic resonance imaging is further used to ameliorate the precise diagnosis of CHF. This medical device utilizes powerful magnets to create a process that sets off the nuclei field of atoms in the heart cells vibrating. The oscillating atoms emit radio signals which are converted by computer into either stationary or moving 3-D images. This non-invasive procedure visualizes the heart and vascular structures and functions without exposing the patients to radiation and iodinated contrast dye which is widely used with the risk of iatrogenic disease. Proficient physicians are able to read the results of $\mathrm{MRI}$, interpret it to enhance their diagnosis of CHF (Ebomoyi, 2010).

Although treatment may improve cardiac function and prolong life expectancy, left untreated $\mathrm{CHF}$ could easily lead to death. CHF is most often accompanied by reduced quality of life and functional capabilities. CHF is second only to coronary disease as the most common 
underlying cause of sudden death in United States. In an effort to avoid an unnecessary mortality associated with $\mathrm{CHF}$, this project was designed to:

- Explore the morbidity and mortality associated with congestive health disease

- Analyze genomic epidemiology of congestive heart disease

- Identify modifiable and non-modifiable risk factors associated with CHD

- Propose nutritional interventions to combat congestive heart disease and

- Advocate the adoption of predictive, preventive, personalized and participatory approaches to reduce the mortality and morbidity associated with congestive heart disease.

\section{TRENDS IN MORBIDITY AND MORTALITY ASSOCIATED WITH CHD}

By 1990, in United Sates, congestive heart disease constituted the underlying cause of death involving 38,000persons and approximately $92 \%$ were persons aged equal or over 65years (Figure $1 \& 2$ ). In the same year, the frequency of mortality associated with CHD was 37,935 . The crude death rate for congestive heart disease was 559.1per 100,000. The most recent data from the American Heart Association (AMA) revealed that CHD affects 5 million Americans yearly, with 550,000 new cases yearly. The frequency of incidence data on CHD exceeds those of AIDS, breast cancer or Alzheimer's disease. CHD is not only the most common cause of hospitalization in patients over 65years of age, but also responsible for approximately 1 million hospitalization annually. CHD contributes to 300,000 deaths yearly. In 2006, the United States health care system expended an estimated $\$ 29.6$ billion to treat congestive heart failure. This study is an attempt to educate the public and those at risk to $\mathrm{CHF}$ about innovative educational techniques to prevent the incipient onset of the disease.

\section{GENOMIC EPIDEMIOLOGY OF CHD}

Regarding congenital heart disease gene in chromosome3P25, the critical region was reduced to an interval between D3S1263 and D3S3594. The candidate agents such as 3P25 CHD gene, PMCA2 (ATP2B2), and fibulin2, TIMP4 andSec13R were reported to map outside the target interval. The largest study ever completed of genetic factors associated with heart attacks, identified nine genetic regions out which three had not been previously characterized (German, 2003). A team of scientists assessed the SNP of 26,000 subjects from ten countries, using the international Haplotype Map, a comprehensive map of SNPs across the genome. The other technology used included the genotyping arrays and gene chip developed by Altshuler's Group (2008).

Their investigation revealed significant association in nine genetic regions with heart attackassociated risks. The known chromosomal variant isolated by this group is a gene called PGSK9 which was originally reported by Kathresan (2009). Medical scientists, cardiologists and other clinicians now believe that since an effective intervention currently exist for the management of heart attack, new patients at a higher genetic risk may benefit from earlier treatment modality. 


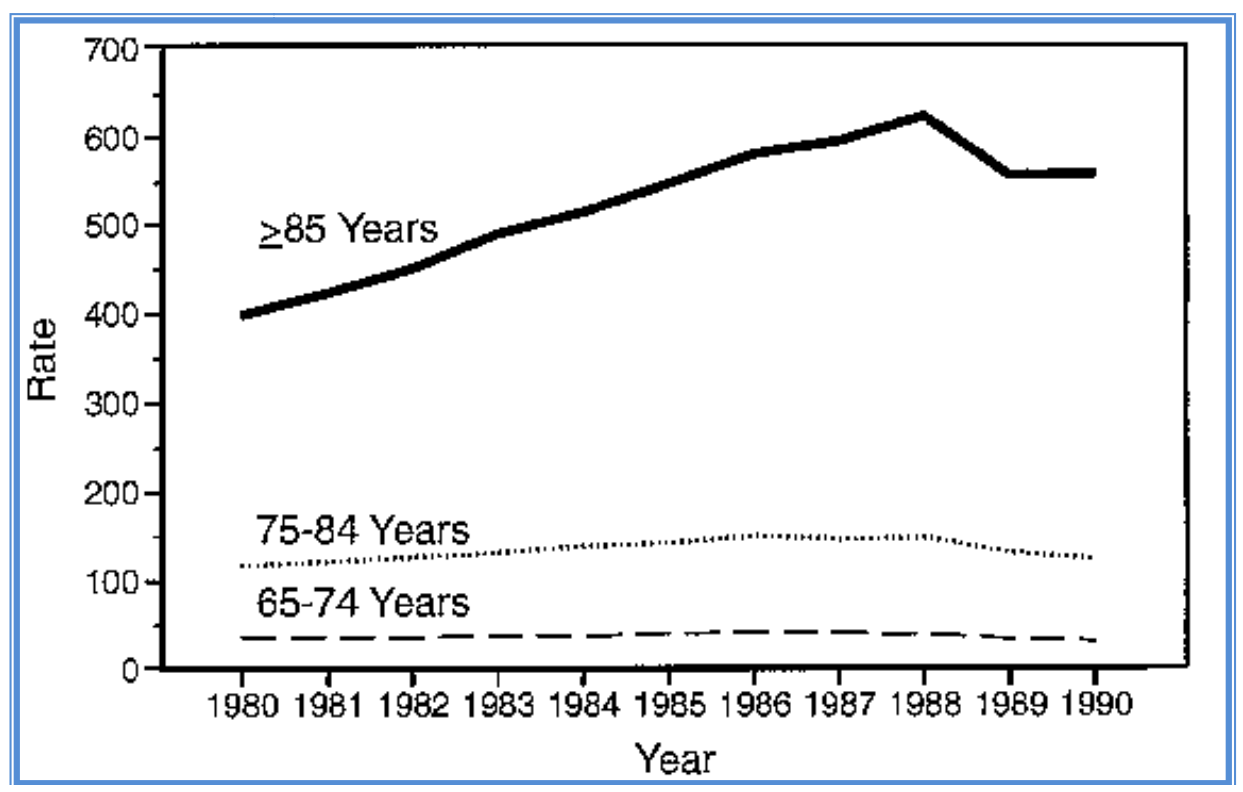

Fig. 1. Age-specific crude death rate ${ }^{*}$ for congestive heart failure ${ }^{+}$for persons aged $\geq 65$ years by age group - United States, 1980-1990

('Per 100,000 populations; ${ }^{+}$International Classification of Diseases, Ninth Revision, codes 428.0-428.9) 


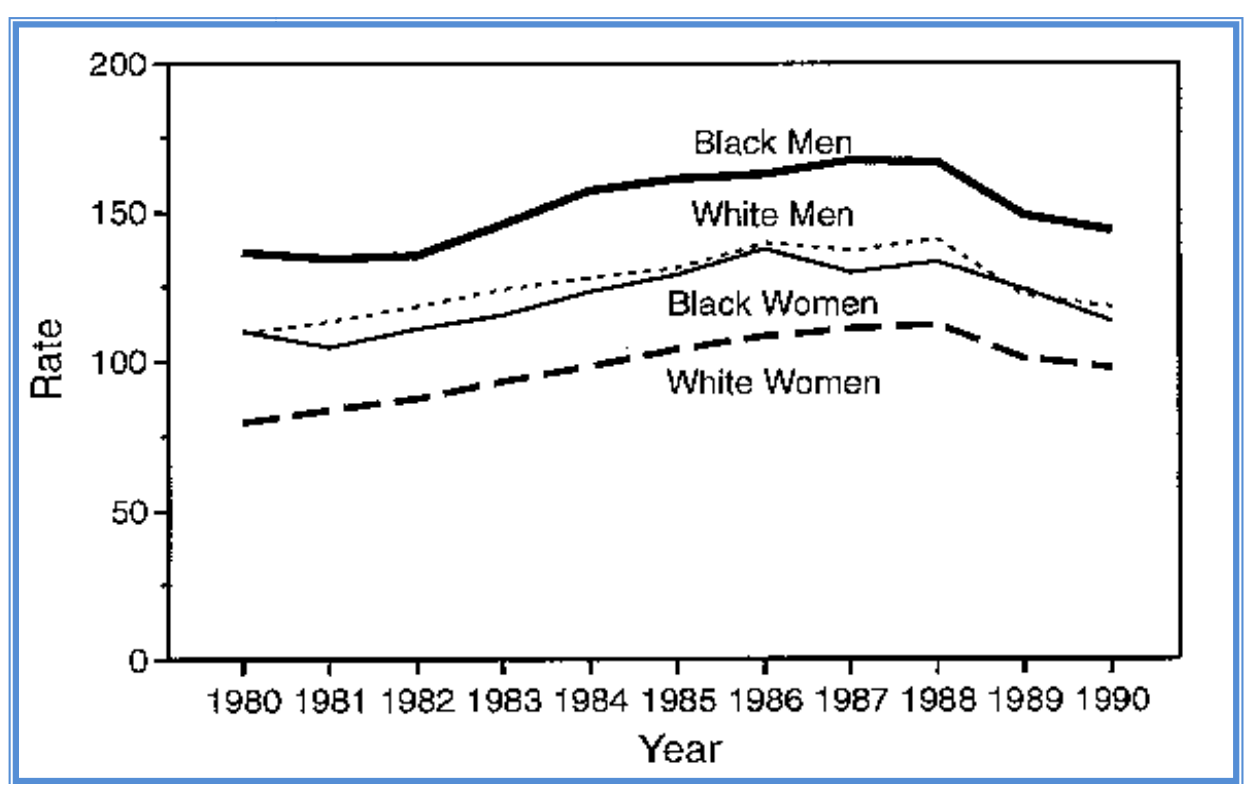

Fig. 2. Age-adjusted death rate ${ }^{*}$ for congestive heart failure ${ }^{+}$for persons aged $\geq 65$ years by race $\$$ and sex - United States, 1980-1990

('Per 100,000 populations; standardized to the 1980 U.S. Bureau of the Census population;

+ International Classification of Diseases, Ninth Revision, codes 428.0-428.9;

${ }^{\$}$ Race-specific denominator data were available only for blacks and whites) 
Recently, an international team of researchers has successfully identified new gene variants associated with an increased risk of myocardial infarction (MI). The new genes they identified were detected after having studied a million genetic biomarkers in 1,200MI patients (Murabito et al., 2003). From their healthy counterparts, the genes for MI were found to be located on chromosome 3 and 12. Scientists now suspect one of the genes, the MRSA gene, as playing significant role in the onset of cardiovascular disease. Also, a second gene described as HNF1A was described to be closely associated with cholesterol metabolism (McPherson et al., 2007).

At present, the Genome Wide Association study has only revealed some inkling about specific chromosomes and specific alleles which are associated with CVD. However, there are over 1400 genes associated with 1200 Mendelian traits and only about 10 to 15 of them are the etiologic genetic variants for complex diseases (McMarthy et al., 2008). Epidemiologists are interested in testing for the authenticity of some of these clinical tests by determining the specificity, sensitivity, positive and negative predictive indices and efficiency of these genetic tests. In an investigation reported by Smith et al., (2009) using the genomewide association study, they replicated common genetic variants on chromosome 9p21 to confer risk of coronary heart disease. They also hypothesized the association of these SNPs with ischemic stroke, because previous studies claimed overlapping heritability of myocardial infarction and ischemic stroke principally due to a common atherosclerotic pathogenesis. The caveat about the genetics of ischemic stroke is a field that has been long plagued by non-replication of reported findings, accentuating the equivocal results of complex traits (Altshulers et al., 2008).

Frazier et al. (2005) delineate some of the non-modifiable etiologies of CHF from a review of genetic studies. The genes identified for the various cardiomyopathies are summarized in Table 1. These heart failure-associated diseases consist of primary cardiomyopathies, mixed cardiomyopathies that involve altered cardiac muscle including generalized multi-organ disorders and other associated diseases.

Even by 1980, a genetic association with familial cardiomyopathy was postulated. Then the identification of alpha actins (ACTC) was published as the etiologic agent for DCM gene. Echocardiography and other genetic studies were instrumental in indicting sarcomere mutation in $25 \%$ to $30 \%$ of asymptomatic relatives of patients with dilated cardiomyopathies. Consistent with findings from the human genome sequencing of April 2003, the frequency of disease causing DCM genes were up to 20 or more.

\section{ANALYTICAL VALIDITY, CLINICAL VALIDITY AND CLINICAL UTILITY}

Epidemiologists are interested in testing for the authenticity of some of this clinical test by determining the specificity, sensitivity, positive predictive and negative predictive value and the efficiency of a test. The Federal Centers for Disease Control and Prevention (CDC, 2008) recently developed an acronym (ACCE) which stands for the four components of epidemiological evaluation in genomic science. These clinical evaluation techniques are analytical, clinical validity and clinical utility. The analytical validity of a test is the ability of the genetic test to measure accurately and reliably the genotype in question. 
Table 1. Genes that cause Dilated Cardiomyopathy

\begin{tabular}{|c|c|c|c|c|}
\hline Protein Type & Protein Name & Gene & Phenotype & "Year \\
\hline \multirow[t]{2}{*}{ Cytoskeleton } & Dystrophin & $D M D$ & $\mathrm{D} / \mathrm{M}$ & 1991 \\
\hline & Delta Sarcoglycan & $S G C D$ & $\mathrm{D} / \mathrm{M}$ & 1997 \\
\hline \multirow[t]{7}{*}{ Sarcomere } & Beta Myosin heavy chain & MYH7 & $H / D$ & 1989 \\
\hline & Alpha Actin & ACTC & $H / D$ & 1998 \\
\hline & Troponin T & TNNT2 & $H / D$ & 1995 \\
\hline & Alpha Tropomyosin & TMP1 & $H / D$ & 1994 \\
\hline & Troponin I & TNNI3 & $H / D / R$ & 1997 \\
\hline & Troponin C & TNNC1 & $H / D$ & 2004 \\
\hline & Myosin binding protein $\mathrm{C}$ & MyBPC3 & $H / D / R$ & 1995 \\
\hline \multirow[t]{5}{*}{$\begin{array}{l}\text { Sarcomere/Z-disc } \\
\text { proteins }\end{array}$} & Titin & TTN & $H / D$ & 1999 \\
\hline & Titin-cap/telethonin & TEL & $\mathrm{H} / \mathrm{D} / \mathrm{M}$ & 2002 \\
\hline & Muscle LIM protein & CRP3 & $H / D$ & 2002 \\
\hline & Metavinculin & VCL1 & $\mathrm{D}$ & 2002 \\
\hline & Cypher/ZASP & $\angle D B 3$ & D/LVNC & 2003 \\
\hline \multirow[t]{3}{*}{ Channel proteins } & Cardiac sodium channel & SCN5A & $\mathrm{D} / \mathrm{A}$ & 1995 \\
\hline & ATP-sensitive potassium & SUR2A/ABBCC9 & $D / A$ & 2004 \\
\hline & Phospholambin & PLN & $\mathrm{D}$ & 2003 \\
\hline \multirow[t]{2}{*}{$\begin{array}{l}\text { Intermediate filament } \\
\text { proteins }\end{array}$} & Desmin & $D E S$ & $\mathrm{D} / \mathrm{R} / \mathrm{M}$ & 1999 \\
\hline & Lamin A/C & LMNA & $\mathrm{D} / \mathrm{M} / \mathrm{L}$ & 1999 \\
\hline Mitochondria & Tafazzin & G4.5/TAZ & D/LVNC & 1997 \\
\hline
\end{tabular}

*Year in which the gene was first associated with cardiac phenotype/cardiomyopathy.

H-hypertrophic cardiomyopathy; D-dilated cardiomyopathy; R-restrictive cardiomyopathy; M-muscular dystrophy; L-lipodystrophy; LVNC-left ventricular noncompaction; A-arrhythmias.

Source: Frazier et al. (2009).

Analytical sensitivity demands responses to what is the percentage accuracy of the genetic test in detecting that sickle cell anemia is actually present. On the other hand, analytical specificity focuses on the probability that the technology indicates that the disease is not present, when in actual fact, the disease has not existed in the patient. Quality control measures the procedures for ensuring that the test results fall within specified and acceptable limit. Clinical validity focuses on the ability of a test to detect the associated phenotypes and the relevant four components are clinical sensitivity, clinical specificity, prevalence of specific disorder in the society, and the positive and negative predictive indices, penetrance and other modifiers such as environmental variables (CDC, 2008). 
Clinical utility defines the factors that must be considered when evaluating the risks and benefits associated with the introduction of genetic tests procedures into the community. For instance, why should individuals who have completed their child-bearing years be tested for sickle cell anemia? Geneticists, physicians and other providers could unwittingly start exposing those screened to alleles of genetic diseases without any known cure.

Economic validity addresses the cost and benefits of testing and what is the existing workforce or capacity to provide counseling to healthcare recipients of genetic tests. Are their qualified medical geneticists to provide pre- and post-genetic screening counseling services with the requisite follow-up programmes? Are there primary preventive educational services in the area? These issues are most germane to personalized medical service worldwide. In personalized medicine, these critical issues must be dealt with the commercialization of individualized medical services to unsuspecting public. This land-rush in individualized medicine must be monitored until the comprehensive genomic profiles can be obtained at a cost that is affordable and at those sites that are accessible to patients.

\section{PHARMACOGENOMICS}

Researchers define pharmacogenomics as the science that investigates how individuals react to medication. The World Health Organization (WHO) has explained pharmacogenomics as the study of DNA sequencing of variation as it relates to differential drug response in individuals. This entails application of genomic technology to determining an individual's response to specific drugs in order to avoid adverse drug events (WHO, 2011). The United States Department of Energy therefore emphasized that pharmacogenomics as "moving away from one size fits all" therapeutics. The cogent rationale pertains to the need for medical scientists and epidemiologists to correlate DNA variants with individual patient's responses to medical treatment and identify drugs which are customized to specific cohorts of patients. Therefore the discipline that blends pharmacology with genomic capabilities is referred to as "pharmacogenomics."

The advantages of this innovative science are many and varied: It can contain cost of management of congestive heart disease, enable physicians to avert deadly clinical errors, and protect patients from unnecessary and untimely death and restore their confidence in medical practice derived from genomic research. Currently state of the art knowledge about pharmaco-genomics continues to enhance the treatment of patients with congestive heart disease through the application of Warfarin to dissolve blood clot in many patients.

\section{WARFARIN AND ATRIAL FIBRILLATION}

With cardiovascular disease as the leading cause of death worldwide, the significant scientific breakthrough in genomics has been exemplified in the genetic testing when physicians prescribe the anti-blood clothing agents, Warfarin (Coumadin). This drug which was prescribed to well over thirty million patients in the United States alone, had mixed therapeutic benefits. The intended uses were to prevent the following conditions: deep venous thrombosis, pulmonary embolism, blood clots associated with heart arrhythmia (atrial fibrillation), blood clot associated with artificial heart valve replacement and recurrent myocardial infarction. With the recent innovations in genomics physicians are now able to titrate the patient's specific Warfarin dosage on the basis of the International Normalized Ratio (INR) to determine values which reflect the patient's blood tendency to clot. Warfarin as an anticoagulant must be taken in 5 or $7.5 \mathrm{mg}$ dosage for the management and 
prevention of thrombo-embolic disease. If the INR is found to be too high, this indicates a high risk of bleeding and if too low, the drug is not exerting enough anticoagulant effect. From these clinical findings and other genomic and anthropometric data, the dosage will be adjusted upward to enhance efficacy.

This pharmacogenomic intervention enhances patient's safety. Scientific studies have revealed that variants in two genes account for about one-half of the differences in warfarin metabolism in patients. The outcome of this clinical study has conferred tremendous health benefits for the large number of patients who suffer from atrial fibrillation which is among the lethal form of heart diseases. The individualized approach will allow us to preempt diseases before they occur by utilizing the participation of individual or communities. This will occur at the incipient stages to the endpoint of a disease process.

The educational caveat for all patients is to monitor the amount of vitamin K-rich foods which they consume to enhance the therapeutic benefits of Caumadin. If a patients experiences symptoms such as bleeding, pain, swelling, discomfort, bruises, pink or brown urine, coughing up blood, or vomiting, they must inform their health care provider immediately.

\section{Box 1. Foods rich in Vitamin $\mathrm{K}$}

\begin{tabular}{|llll|}
\hline Asparagus & Cauliflower & Kale & Sauerkraut \\
Avocado & Coleslaw & Lentils & Soybeans \\
Broccoli & Collard greens & Lettuce & Spinach \\
Brussels sprouts & Endive & Liver & Swiss chard \\
Cabbage & Garbanzo beans & Mustard Greens & Turnip greens \\
\hline
\end{tabular}

\section{INNOVATIVE (P4) MEDICINE: PREDICTIVE, PREVENTIVE, PERSONALIZED AND PARTICIPATORY}

Today, an improvement in the technology for biochemical analysis of patients' specimen has enhanced the knowledge about the incipient signs of diseases, diagnosis, treatment and prevention of these diseases. The recently developed technologies most relevant to genomics science include 454 life sequencers, manufactured by Roche Diagnostics (Brandford, CT), chromatography and electrophoresis, gene amplification, capillary analysis, polymerase chain reaction tests, micro array sequencing and iso-electric focusing. These innovative technologies and bio-informatics have the potential to provide relevant insights into the disease manifestation in individual patients and the clinical differences at molecular level. It is such knowledge that will enable the physicians to tailor treatment to the precise needs of patients. After the accomplishment of the human genome sequencing (HGS), personalized medicine could include testing for variations in genes, gene expression, proteins and metabolites. In more sophisticated comprehensive patient's assessment, the results of the patient's HGS will compliment anthropometric data which are likely to correlate with drug response, disease state, treatment prognosis, including patient's behavioral lifestyle such as exposure to stressful lifestyle, use of tobacco, alcohol and her nutritional habits.

Realistically, use of these comprehensive tests and use of molecular assessment and the inevitable ability of these composite test results to predict susceptibility to disease implies that personalized medicine has the potential to significantly transform not only the United 
States national health care system but also the democratization of services so as to enhance the quality of life and elongate the human life-expectancies.

Precision medicine which was described by Dr. Elias Zerhouni (2010), the former director of the National Institutes of Health $(\mathrm{NIH})$, is the innovative medicine which must anticipate and interrupt the disease process, thereby preventing the patient from being overwhelmed by the actual disease burden. This innovative medical paradigm is now characterized as P4 medicine:

(1) Predictive approach is the development of probabilistic health projection for a person based on their DNA, or sequenced chromosome, and protein expression.

(2) Preventive medicine is the creation of interventions or therapeutic that will prevent a disease that an individual is assessed to have a high probability of developing. Regarding CVD, counseling of young adults which involves the requisite health behaviors particularly about the avoidance of tobacco, and the ingestion of food items that are rich in lipids and high salt content so as to avoid CVD is very important.. Although age is a pathogmonomic risk factor, exercise and compliance with adequate health habits can be play significant protective against many heartproblems.

(3) Personalized medicine refers to treating individuals based on their unique human genetic variations. For example, what are their sequenced DNA and haplotype characteristics? Does the patient have inherited chromosomes that place such a patient at risk? For example, with emerging Alpha-adducin, the therapeutic intervention could be ACE inhibitors with hypertensive patients if patient's safety is considered. With CYP2C9/VKORC1, as the target, Warfarin is most appropriate for blood clot and congestive heart disease.

(4) Participatory medicine implies a patient's active, informed involvement in their medical choices, treatment, and acting in partnership with their health care providers. A patient must be health-educated enough to inform a physician if the parents died from cardiovascular disease, such as heart failure, coronary disease or myocardial infarction (Institute of System Medicine, 2010).

Many technological sequencing devices relevant to CVD have been developed in recent times. Such knowledge will enable the physician to tailor treatment to the precise needs of patients.

A comprehensive list of the state of the art technologies required to improve the dissemination of personalized health care services was compiled by Ebomoyi and Srinivasan (2008). In the era of genomic medicine, the key benefits of predictive, preventive, personalized and participatory interventions to the patient include new abilities to:

- Detect disease at an earlier stage, when it is easier and less expensive to treat effectively

- Stratify patients into groups that enable the selections of optimal therapy

- Reduce adverse drug reactions by more effective early assessment of individual drug responses

- Improve the selection of new biochemical targets for drug discovery 
- Reduce the time, cost, and failure rate of clinical trials for new therapies

- Shift the emphasis in medicine from reaction to prevention and from disease to wellness.

\section{NUTRITIONAL INTERVENTIONS/NUTRIGENOMICS}

Another crucial intervention against congestive heart diseases is efficiently tailored nutritional education for patients emphasizing the role of phytonutrients in their diet. Nutrigenomics is intricately linked to the scientific knowledge about the types and quantity of food consumed and their effect in human genome. Research conducted by Peterson et al. (2005) substantiated the chemo-protective impact of cruciferous vegetables such as broccoli and Brussels sprouts in fortifying human immune system and preventing cancer. Other food items known to reduce the impact of CHF include banana, strawberries, oranges, and apples. However, the foods items and food addictives that CHF patient must avoid for a longer life-expectancy have been summarized in Table 2. Specifically, food rich in lipids, salt, excess sugar are recognized to trigger increased blood pressure and possible atrial fibrillation in many patients.

\section{RELEVANT HEALTH EDUCATION}

The diet of the congestive heart disease patient must be rich in whole grains, whole-wheat pasta, raisin bran, barley, oatmeal, oat brown muffins, brown rice, or whole-wheat bread.

Many phyto-nutrients are derived from the following fruits such as raspberries, apples, pears, strawberries, bananas, blackberries, blueberries, mangoes, apricots, citrus fruits, dried fruits, prunes and raisins. Legumes which are nutritionally therapeutic include: lentil, black beans, split peas, lima beans, baked beans, kidney beans, pinto, chick peas, navy beans, and black-eye peas. Vegetables that are very rich in phytonutrients and beta carotenes consist of: broccoli, spinach, dark green leafy vegetables, peas, artichokes, carrots, tomatoes, Brussels sprouts, and potatoes and yams (Oshifuye, 2011).

The combined nutrients from the food items explored contain multiple vitamins such as $E$ which acts as antioxidants assisting in blood to reduce the amount of oxidized low density lipoproteins that is formed. Beta-carotene is among the other vitamins with antioxidants which in human diet aids in reducing the risk of congestive heart disease. The $\mathrm{B}$ vitamins consisting of $B_{6}, B_{12}$, and folic acid (foliate). These vitamins play a vital role in protecting patients against heart disease.

\section{CONCLUSION}

Genomics now enables educators and clinicians to recognize the role of non-modifiable risk factors in the incipient onset of $\mathrm{CHF}$, therefore it is imperative that at risk cohort must visit their physicians for routine checkup annually. The need to abstain from tobacco, excessive salt and sugar consumption cannot be over-emphasized. Although vital amino-acids exist in red meat for human insulation, it must be consumed only sparingly. The choice of lean meat, fish such as salmon or cat fish, turkey, chicken can be consumed ensuring the quantity of plant-derived foods are over at least 60 percent. Even with the newest nationally recommended food guide, the meat products are less than 20 percent. 
Table 2. Some Food Additives to be Avoided

\begin{tabular}{|c|c|c|}
\hline Name & Usage & Facts you need to know \\
\hline $\begin{array}{l}\text { Allura } \\
\text { Red AC }\end{array}$ & $\begin{array}{l}\text { Food coloring in snacks, } \\
\text { sauces, preserves, soups, } \\
\text { wine, cider, etc. }\end{array}$ & $\begin{array}{l}\text { Avoid if you suffer from asthma, rhinitis } \\
\text { (including hayfever), or urticaria (hives). }\end{array}$ \\
\hline Amaranth & $\begin{array}{l}\text { Food coloring in wine, } \\
\text { spirits, fish roe. }\end{array}$ & $\begin{array}{l}\text { Banned in the U.S. Avoid if you suffer } \\
\text { from asthma, rhinitis, urticaria or other } \\
\text { allergies. }\end{array}$ \\
\hline Aspartame & $\begin{array}{l}\text { Sweetener in snacks, } \\
\text { sweets, alcohol, desserts, } \\
\sim \text { diet" foods }\end{array}$ & $\begin{array}{l}\text { May affect people with PKU } \\
\text { (phenylketonuria). Recent reports show } \\
\text { possibility of headaches, blindness, and } \\
\text { seizures with long-term high doses of } \\
\text { aspartame. }\end{array}$ \\
\hline Benzoic acid & $\begin{array}{l}\text { Preservative in many foods, } \\
\text { including drinks, low sugar } \\
\text { products, cereals, meat } \\
\text { products. }\end{array}$ & $\begin{array}{l}\text { Can temporarily inhibit the function of } \\
\text { digestive enzymes. May deplete glycine } \\
\text { levels. Avoid ifyou suffer from asthma, } \\
\text { rhinitis, urticaria or other allergies. }\end{array}$ \\
\hline $\begin{array}{l}\text { Brilliant } \\
\text { Black BN }\end{array}$ & $\begin{array}{l}\text { In drinks, sauces, snacks, } \\
\text { wines, cheese, etc. }\end{array}$ & $\begin{array}{l}\text { Avoid if you suffer from asthma, rhinitis, } \\
\text { urticaria, or other allergies. }\end{array}$ \\
\hline $\begin{array}{l}\text { Butylated Hydroxy- } \\
\text { anisole }\end{array}$ & $\begin{array}{l}\text { Preservative, particularly in } \\
\text { fat-containing foods, } \\
\text { confectionery, meats. }\end{array}$ & $\begin{array}{l}\text { The International Agency for Research } \\
\text { on Cancer says BHA is possibly } \\
\text { carcinogenic to humans. BHA also } \\
\text { interacts with nitrites to form chemicals } \\
\text { known to cause changes in the DNA of } \\
\text { cells. }\end{array}$ \\
\hline Calcium benzoate & $\begin{array}{l}\text { Preservative in many foods, } \\
\text { including drinks, low-sugar } \\
\text { products, cereals, meat } \\
\text { products. }\end{array}$ & $\begin{array}{l}\text { Can temporarily inhibit function of } \\
\text { digestive enzymes and may deplete } \\
\text { levels of the amino acid glycine. Should } \\
\text { be avoided by those with hay fever, } \\
\text { hives, and asthma. }\end{array}$ \\
\hline Calcium sulphite & $\begin{array}{l}\text { Preservative in a vast array } \\
\text { of foods-from burgers to } \\
\text { biscuits, from frozen } \\
\text { mushrooms to horseradish. } \\
\text { Used to make old produce } \\
\text { look fresh. }\end{array}$ & $\begin{array}{l}\text { In the U.S., sulphites are banned from } \\
\text { many foods, including meat. They can } \\
\text { cause bronchial problems, flushing, low } \\
\text { blood pressure, tingling, and anaphylactic } \\
\text { shock. The International Labour } \\
\text { Organization says avoid them ifyou suffer } \\
\text { from bronchial asthma, cardiovascular or } \\
\text { respiratory problems and emphysema. }\end{array}$ \\
\hline
\end{tabular}




\begin{tabular}{|c|c|c|}
\hline $\begin{array}{l}\text { Monosodium } \\
\text { glutamate (MSG) }\end{array}$ & Flavor enhancer. & $\begin{array}{l}\text { Has been known to cause pressure on } \\
\text { the head, seizures, chest pains, } \\
\text { headache, nausea, burning sensations, } \\
\text { and tightness of face. Many baby food } \\
\text { producers have stopped adding MSG to } \\
\text { their products. }\end{array}$ \\
\hline $\begin{array}{l}\text { Ponceau 4R, } \\
\text { Conchineal } \\
\text { Red A }\end{array}$ & Food coloring. & $\begin{array}{l}\text { People who suffer from asthma, rhinitis or } \\
\text { urticaria may find their symptoms } \\
\text { become worse following consumption of } \\
\text { foods containing this coloring. }\end{array}$ \\
\hline $\begin{array}{l}\text { Potassium } \\
\text { benozoate }\end{array}$ & See calcium benzoate. & See calcium benzoate. \\
\hline Potassium nitrate & $\begin{array}{l}\text { Preservative in cured meats } \\
\text { and canned meat products. }\end{array}$ & $\begin{array}{l}\text { It can lower the oxygen-carrying capacity } \\
\text { of the blood; it may combine with other } \\
\text { substances to form nitrosamines, which } \\
\text { are carcinogenic; and it may have an } \\
\text { atrophying effect on the adrenal gland. }\end{array}$ \\
\hline $\begin{array}{l}\text { Propyl p- } \\
\text { hydroxybenozoate, } \\
\text { propylparaben, } \\
\text { and paraben }\end{array}$ & $\begin{array}{l}\text { Preservative in cereals, } \\
\text { snacks, pate, meat } \\
\text { products, confectionery. }\end{array}$ & $\begin{array}{l}\text { Parabens have been identified as the } \\
\text { cause of chronic dermatitis in numerous } \\
\text { instances. }\end{array}$ \\
\hline $\begin{array}{l}\text { Saccharin \& its } \\
\mathrm{Na}, \mathrm{K} \text { and } \mathrm{Ca} \text { salts }\end{array}$ & $\begin{array}{l}\text { Sweetener in diet, and no- } \\
\text { sugar products. }\end{array}$ & $\begin{array}{l}\text { The International Agency for Research } \\
\text { on Cancer has concluded that saccharin } \\
\text { is possibly carcinogenic to humans. }\end{array}$ \\
\hline $\begin{array}{l}\text { Sodium } \\
\text { metabisulphite }\end{array}$ & $\begin{array}{l}\text { Preservative and } \\
\text { antioxidant. }\end{array}$ & $\begin{array}{l}\text { May provoke life-threatening respiratory } \\
\text { problems. }\end{array}$ \\
\hline Sodium sulphite & $\begin{array}{l}\text { Preservative used in wine- } \\
\text { making and other processed } \\
\text { foods. }\end{array}$ & $\begin{array}{l}\text { Sulphites have been associated with } \\
\text { triggering asthma attacks. Most } \\
\text { asthmatics are sensitive to sulphites in } \\
\text { food. }\end{array}$ \\
\hline
\end{tabular}

\section{REFERENCES}

Altshulers, D., Daly, M.J., Lander, E.S. (2008). Genetic mapping in human disease. Science, 322(5903), 881-888.

CDC. Monthly Morbidity and Mortality Weekly (MMWR). (1994). Mortality from congestive heart failure-United States., 1980-1990, pp1-5.

Ebomoyi, E.W. (2010). Framingham heart study, the legacy and health education implications in the age of genomic medicine. Researcher, 2(6), 33-43.

Ebomoyi, E.W., Srinivasan, S. (2009). Innovations in capacity building in genomic technology in the United States. Int. J. Medical Eng. Informatics, 1(2), 210-226. 
Danami, S.B., Topol, E.J. (2009). Molecular genetics of atrial fibrillation. Genomic Med., 1(54), 36-41.

Frazier, L., Johnson, R.L., Sparks, E. (2005). Genomics and cardiovascular disease. J. Nursing Scholarship, 37(4), 315-321.

Frazier, L., Wung, S.F., Parks, E., Eastwood, C. (2009). Cardiovascular Nursing on human genomics: What do cardiovascular nurses need to know about congestive heart failure? Pro. Cardiovascular Nurs., 24(3), 80-85.

German, J.B., Roberts, M.A., Watson, S.M. (2003). Genomics and metabolomics as markers for the interaction of diet and health: lessons for lipids. J. Nutr., 2(133), 20785s-2083S.

Institute of System Medicine. (2010). Definition of P4 Medicine info@ismedicine.org. Retrieved July, 2011.

Kathiresan, S. (2010). Gene variants associated with early heart attack identified Science daily http://www.sciendaily.com/releases/2009/02/0908133223.html. Retrieved May 12th, 2010.

Khoury, M. J., Bealy, T.H., Cohen, B.H. (1993). Fundamental of genetic epidemiology. New York, Oxford University Press.

Mausner, J.S., Bahn, A.K. (1987). Epidemiology, An introductory text Philadelphia. W. Saunders, pp1-3 21-30.

McCarthy, M.I., et al. (2008). Genome-wide association studies for complex traits: consensus, uncertainty and challenges. Nature, 9, 356-369.

McPherson, R., et al. (2007). A common allele on chromosome 9 associated with coronary heart disease Science, 316(5830), 1488-1491.

Murabito, J.M., O'Donnell, C.J., Vasan, R.S., Wolf, P.A., Levy, D. (2007). The third generation cohort of the National Heart, Lung, and blood Institute's Framingham Heart Study: design, recruitment, and initial examination. Am. J. Epidemiol., 165(11), 132835.

Oshifuye, F. (2011). Garden eggs: Chewing thoroughly gives maximum benefits. Vanguard National Newspaper, pp. 1-5

Peterson, S., Biglar, J., Horner, N.K., Poller, J.D., Lamp, J.W. (2005). Cruciferae interact with UGT1A1* 28 polymorphism to determine serium bilirubin levels in humans. J. Nutr., 135(5), 1051-5, PMID15861280.

Smith, J.G., et al. (2009). Common genetic variants on chromosome 9P21 confers risks of ischemic stroke: A large scale genetic association study Cardiovascular Genetic, (2), 159-164.

World Health Organization. (2002). Pharmacogenenetics: ethical issues. Report by the Nuffield Council of Bioethics http://www.who.int/genomics/elsi/phamacogenomics. Retrieved July 20, 2011.

Zerhouni, E.A. (2009). Transforming NIH and the promise of research www.asnonline.org/...NIH. Retrieved March 30, 2010.

(C) 2011 Ebomoyi; This is an Open Access article distributed under the terms of the Creative Commons Attribution License (http://creativecommons.org/licenses/by/3.0), which permits unrestricted use, distribution, and reproduction in any medium, provided the original work is properly cited. 